\title{
Studies on Ferrochelatase
}

\section{ASSAY AND PROPERTIES OF FERROCHELATASE FROM A PIG-LIVER MITOCHONDRIAL EXTRACT}

\author{
BY R. J. PORRA AND O. T. G. JONES \\ Division of Plant Industry, C.S.I.R.O., Canberra, A.C.T., Australia
}

(Received 20 August 1962)

The name 'ferrochelatase' has been given to the enzyme system that catalyses the insertion of $\mathrm{Fe}^{2+}$ ions into protoporphyrin to form protohaem (Rimington, 1958). The state of reduction of the porphyrin substrate of ferrochelatase is uncertain. Although haem was formed in the presence of protoporphyrinogen (Nishida \& Labbe, 1959), prior oxidation to protoporphyrin may have occurred. Nishida \& Labbe also demonstrated an initial lag phase in ferrochelatase activity which was abolished by preincubation of protoporphyrin with their enzyme preparation in the absence of $\mathrm{Fe}^{2+}$ ions. This suggested that protoporphyrin might be converted into an active intermediate, perhaps a reduced form. Such a suggestion was attractive because of the established importance of porphyrinogens in haem biosynthesis. That metal ions can be incorporated into reduced porphyrins has been demonstrated in non-enzymic studies by Orlando (1958) and Heikel, Lockwood \& Rimington (1958), and molecular configurations that facilitate such an incorporation of metal ions into reduced porphyrins have been proposed (Orlando, 1958; Lemberg, 1961; Phillips, 1961).

In the present paper we describe a rapid assay for ferrochelatase activity depending on the formation of pyridine haemochromogen from the synthesized haem. A soluble ferrochelatase system, extracted from pig-liver mitochondria, has been studied and the reduction state of the porphyrin substrate investigated.

\section{EXPERIMENTAL}

\section{Materials}

Hydrochloric acid solutions. Concentrations of aqueous $\mathrm{HCl}$ solutions are given as $\%(w / v)$ to conform with the convention in this field.

Emasol 4130. Emasol 4130 (polyoxyethylenesorbitan mono-oleate) was a gift from the Kao Soap Co., Tokyo, Japan.

Ether. Analytical grade reagent was washed with water until it was free of peroxides (cf. Weissberger, Proskauer, Riddick \& Toops, 1955).

[ $\left.{ }^{59} \mathrm{Fe}\right]$ Ferric citrate. $\left[{ }^{59} \mathrm{Fe}\right] \mathrm{Ferric}$ citrate $(0 \cdot 15 \mu \mathrm{c} / \mu$ mole $)$ was obtained from The Radiochemical Centre, Amersham, Bucks. It was reduced with excess of GSH.
Mesoporphyrin IX. This was obtained from Fluka A. G., Basel, Switzerland. It was dissolved in aq. $0 \cdot 1 \mathrm{~N}-\mathrm{NH}_{3}$, adjusted to $\mathrm{pH} 7.8$ with dilute $\mathrm{HCl}$ and diluted with water to a concentration of $132 \mu \mathrm{m}$-moles $/ \mathrm{ml}$.

Protoporphyrin IX. This was prepared from protohaemin by the method of Morell \& Stewart (1956). The protoporphyrin was extracted at $\mathrm{pH} 4$ into ether, washed well with water and with $0.36 \% \mathrm{HCl}$, and then extracted into $10 \%$ $\mathrm{HCl}$. The protoporphyrin was re-extracted at $\mathrm{pH} 4$ into ether, washed with $0.36 \% \mathrm{HCl}$ and then with water till free of acid. The protoporphyrin was then extracted into aq. $0 \cdot 5 \mathrm{~N}-\mathrm{NH}_{3}$ and the $\mathrm{pH}$ and concentration were adjusted as for mesoporphyrin IX.

Mesoporphyrinogen IX and protoporphyrinogen IX. These were prepared by the reduction with sodium amalgam of mesoporphyrin IX (Mauzerall \& Granick, 1958) and protoporphyrin IX (Sano \& Granick, 1961) respectively. The porphyrins were dissolved in aq. $0.5 \mathrm{~N}-\mathrm{NH}_{3}$ and subsequent manipulations were performed in the dark under $\mathrm{N}_{2}$ to prevent photo-oxidation. The porphyrinogen solutions were adjusted to $\mathrm{pH} 7 \cdot 8$ and diluted with water to a concentration of $100 \mu \mathrm{m}-\mathrm{moles} / \mathrm{ml}$.

Haemoglobin. This was prepared from human blood by the method of Drabkin (1949) and deoxygenated in vacuo before use.

Preparation of pig-liver extract. The entire operation was performed at $4^{\circ}$. Mitochondria were prepared from pig liver by the method of Mahler, Wakil \& Boch (1953). The mitochondrial paste was gently stirred for $2 \mathrm{hr}$. with 3 vol. of $0 \cdot 1 \mathrm{M}-\mathrm{KHCO}_{3}$ containing Tween $20(10 \mathrm{mg} . / \mathrm{ml}$.). The suspension was centrifuged in the Spinco model $L$ centrifuge (30 rotor) for $20 \mathrm{~min}$. at $15000 \mathrm{rev} . / \mathrm{min}$., and the supernatant suspension was recentrifuged for $90 \mathrm{~min}$. at $30000 \mathrm{rev} . / \mathrm{min}$. The supernatant solution was dialysed for $20 \mathrm{hr}$. against two changes of $0 \cdot 1 \mathrm{M}-\mathrm{KHCO}_{3}(20 \mathrm{vol}$.). The yield of extract from fresh liver was approx. $280 \mathrm{ml} . / \mathrm{kg}$. and the protein content (Lowry, Rosebrough, Farr \& Randall, 1951) was about $25 \mathrm{mg}$. $/ \mathrm{ml}$. The protohaem content, assayed as pyridine haemochromogen (see below), was less than $5 \mu \mathrm{m}$-moles $/ \mathrm{ml}$.

\section{Methods}

Determination of ferrochelatase activity by the pyridine haemochromogen method. Pig-liver extract (1.0 ml.) was incubated at $37^{\circ}$ in vacuo in a Thunberg tube with $200 \mu \mathrm{m}$ moles of porphyrin substrate, $400 \mu \mathrm{m}$-moles of $\mathrm{FeSO}_{4}$, $40 \mu$ moles of GSH and $200 \mu$ moles of potassium phosphate at $\mathrm{pH} 7 \cdot 8$. The final volume was $4 \cdot 2 \mathrm{ml}$. The reaction was started by tipping $\mathrm{FeSO}_{4}$ and $\mathrm{GSH}$ from the side arm. Reactions were stopped by opening the Thunberg tube and adding $1.0 \mathrm{ml}$. of pyridine, then $0.5 \mathrm{ml}$. of $\mathrm{N}-\mathrm{NaOH}$ and 
l.0 ml. of water. The mixture was divided equally between two cuvettes and $2 \mathrm{mg}$. of solid $\mathrm{Na}_{2} \mathrm{~S}_{2} \mathrm{O}_{4}$ was added to one cuvette and $0.05 \mathrm{ml}$. of $3 \mathrm{~mm}-\mathrm{K}_{3} \mathrm{Fe}(\mathrm{CN})_{6}$ to the other. The difference spectrum of the reduced and oxidized pyridine haemochromogen was recorded with a Bausch and Lomb Spectronic 505 recording spectrophotometer. Haem was calculated from the equation:

$$
\text { Haem }(\mu \mathrm{m} \cdot \mathrm{moles})=\frac{10^{3} v \cdot \Delta E}{\Delta \epsilon_{\mathrm{mM}}}
$$

where $v$ is the volume (ml.) of alkaline pyridine solution and $\Delta E$ represents the difference in extinction between the maximum of the $\alpha$-band and the minimum occurring between the $\alpha$ - and $\beta$-bands. The values used for $\Delta \epsilon_{\mathrm{mM}}$ were as follows: for pyridine protohaemochromogen,

$$
\epsilon_{\mathrm{mM}}^{557}-\epsilon_{\mathrm{mM}}^{541}=20 \cdot 7 ;
$$

for pyridine mesohaemochromogen,

$$
\epsilon_{\mathrm{mM}}^{547}-\epsilon_{\mathrm{mM}}^{531}=21 \cdot 7
$$

(Porra \& Jones, 1963).

Assay of $\left[{ }^{59} \mathrm{Fe}\right]$ protohaem. To the mixture to be analysed (see Table 2) was added a large excess of carrier haem in the form of $20 \mathrm{ml}$. of chicken blood (containing $115 \mu$ moles of haem), and the haemin was extracted and crystallized by the method of Labbe \& Nishida (1957). Recrystallization did not alter the specific activity significantly. Approx. $10 \mathrm{mg}$. of crystalline haemin was dissolved in $5 \mathrm{ml}$. of $\mathrm{N}-\mathrm{KOH}$ and counted in a well-type scintillation counter (Ekco N664) with a counting efficiency of about $20 \%$. The haem present was determined by the method of Paul, Theorell \& Akeson (1953) and the amount of [ $\left.{ }^{59} \mathrm{Fe}\right]$ protohaem was calculated from the equation:

$$
\begin{gathered}
{\left[{ }^{59} \mathrm{Fe}\right] \text { Protohaem }(\mu \mathrm{m} \text {-moles })=\frac{\text { counts recovered }}{\text { counts added }}} \\
\times \mu \mathrm{m} \text {-equiv. of added } \mathrm{Fe}^{2+} \text { ion. }
\end{gathered}
$$

\section{RESULTS}

\section{Properties of ferrochelatase in pig-liver extract}

Protoporphyrin was used as substrate in several of the following experiments so that comparisons could be made with the results of other workers. Mesoporphyrin was a more convenient substrate since it is more readily converted into haem (Porra \& Jones, 1963) and also more soluble and more stable than protoporphyrin.

Mesohaem formation was found to increase linearly with time up to at least $40 \mathrm{~min}$., but did not increase linearly with enzyme concentration (Fig. 1), for which no satisfactory explanation can yet be given. No mesohaem formation was observed with boiled extracts.

Effect of oxygen on haem formation. Nishida \& Labbe (1959) reported a lag in the reaction when they incubated ferrochelatase with protoporphyrin under a stream of nitrogen. A similar lag phase was observed by us when mesoporphyrin was incubated with a pig-liver extract under a stream of oxygen-free nitrogen without any prior deoxygenation of the incubation mixture, but not when it was incubated in vacuo (Fig. 2). Similar results were obtained when protoporphyrin was used as substrate. Since ferrochelatase activity was completely inhibited by aerobiosis (Table 1) it seemed probable that this lag phase was due to the time required to flush all oxygen from the reaction mixtures. In fact, there was no lag phase when

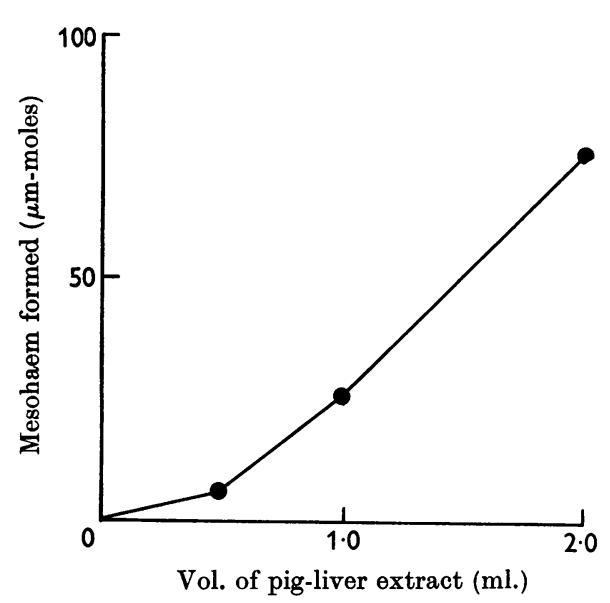

Fig. 1. Enzyme concentration-activity curve for mesohaem formation. The ferrochelatase activity after the $20 \mathrm{~min}$. incubation period was determined by the pyridine haemochromogen assay (see the Methods section).

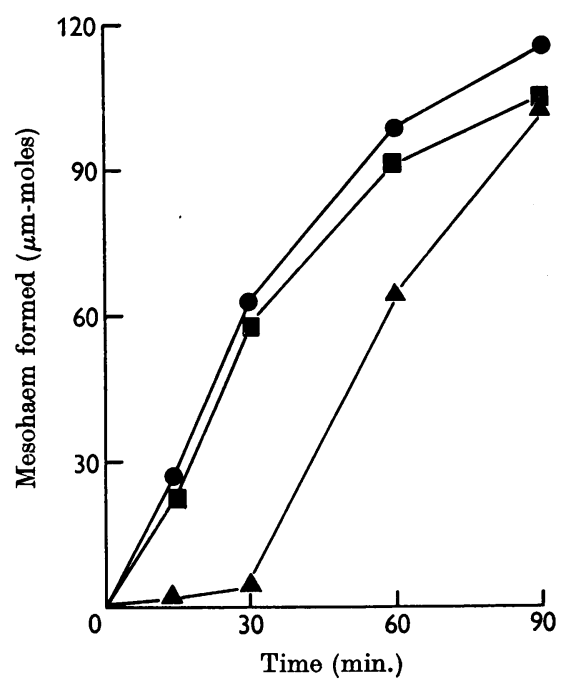

Fig. 2. Mesohaem formation by pig-liver extract determined in vacuo and under a stream of $\mathrm{O}_{2}$-free $\mathrm{N}_{2}$. Ferrochelatase activity was determined by the pyridine haemochromogen assay (see the Methods section). All reactions were started by the addition of $\mathrm{FeSO}_{4}$ and GSH. O, Reaction started after flushing with $\mathrm{O}_{2}$-free $\mathrm{N}_{2}$ for 30 min.; $\boldsymbol{\Delta}$, reaction started without prior flushing; $\boldsymbol{\square}$, reaction performed in vacuo in Thunberg tubes. 
flushing with nitrogen commenced $30 \mathrm{~min}$. before the addition of ferrous sulphate and GSH (Fig. 2).

Reduced porphyrins as substrates. No stimulation of protohaem formation was observed (Table 2) when the soluble enzyme extract was preincubated with protoporphyrin in vacuo with GSH as reductant (cf. Nishida \& Labbe, 1959). Further, when the extract $(2.0 \mathrm{ml}$.) was incubated in vacuo for $20 \mathrm{~min}$. with protoporphyrin and GSH in the absence of $\mathrm{Fe}^{2+}$ ions but under conditions other-

Table 1. Inhibition of mesohaem formation by aerobiosis

Ferrochelatase activity was determined by the pyridine haemochromogen assay (see the Methods section) either under standard conditions (in vacuo) or in the presence of air. Haem was determined as pyridine haemochromogen.

\begin{tabular}{lcc}
$\begin{array}{c}\text { Incubation } \\
\text { conditions }\end{array}$ & $\begin{array}{c}\text { Incubation } \\
\text { period } \\
(\text { min. })\end{array}$ & $\begin{array}{c}\text { Mesohaem } \\
\text { formed } \\
(\mu \mathrm{m}-\mathrm{moles})\end{array}$ \\
Standard (in vacuo) & 20 & $60 \cdot 5$ \\
Standard (in vacuo) & 40 & $122 \cdot 5$ \\
Aerobic & 20 & 0 \\
Aerobic & 40 & 0 \\
\hline
\end{tabular}

Table 2. Effect of preincubation of the ferrochelatase extract with protoporphyrin on $\left[{ }^{59} \mathrm{Fe}\right]$ protohaem formation

The reaction mixture contained pig-liver extract $(0.2 \mathrm{ml}$.$) , protoporphyrin (20 \mu \mathrm{m}$-moles $), \quad\left[{ }^{69} \mathrm{Fe}\right]$ ferrous citrate $\left(6 \cdot 6 \mu \mathrm{m}\right.$-moles; $1 \mu \mathrm{C}$ of $\left.{ }^{59} \mathrm{Fe}\right), \mathrm{FeSO}_{4}(13.4 \mu \mathrm{m}$-moles $)$, GSH $(40 \mu$ moles $)$ and potassium phosphate $(200 \mu$ moles $)$ at $\mathrm{pH} \mathrm{7.8}$; the final volume was $3.9 \mathrm{ml}$. During the preincubation in vacuo $\left(60 \mathrm{~min}\right.$. at $\left.37^{\circ}\right)$ protoporphyrin was omitted from the main compartment of the control Thunberg tubes; the side arms of the control tubes contained $\mathrm{FeSO}_{4}$ and protoporphyrin and the side arms of the other tubes contained only $\mathrm{FeSO}_{4}$. The incubation $(30 \mathrm{~min}$. at $37^{\circ}$ ) was started by tipping in the side-arm contents.

\begin{tabular}{|c|c|c|}
\hline \multirow[b]{2}{*}{ Preincubation conditions } & \multicolumn{2}{|c|}{$\begin{array}{l}\text { Haem formed } \\
\text { ( } \mu \text { m-moles } / \mathrm{ml} \text {. of } \\
\text { enzyme } / \mathrm{hr} .)\end{array}$} \\
\hline & Expt. 1 & Expt. 2 \\
\hline $\begin{array}{l}\text { Enzyme plus protoporphyrin } \\
\text { Control (enzyme alone) }\end{array}$ & $\begin{array}{l}1 \cdot 86 \\
1 \cdot 72\end{array}$ & $\begin{array}{l}1 \cdot 36 \\
1 \cdot 63\end{array}$ \\
\hline
\end{tabular}

wise identical with those in Table 2, no reduced porphyrins could be detected. This incubation was stopped by the addition of concentrated hydrochloric acid $(0.6 \mathrm{ml}$.) and a further $16.0 \mathrm{ml}$. of $5 \%$ hydrochloric acid. This mixture was rapidly transferred to a Spinco (30 rotor) centrifuge tube, flushed with oxygen-free nitrogen, sealed and centrifuged at $10000 \mathrm{rev} . / \mathrm{min}$. for $10 \mathrm{~min}$. The clear supernatant solution was drawn off through a nitrogen-filled line into an evacuated Thunberg cuvette. When the cuvette was opened and the mixture exposed to air and light, which would photochemically oxidize any reduced protoporphyrin intermediate, no increase in extinction at $407 \mathrm{~m} \mu$ was observed. Similar techniques have been successfully employed by Hoare \& Heath (1958) and by Porra (1962) to detect reduced porphyrin intermediates.

When protoporphyrinogen was tested directly as substrate inconsistent results were obtained (Table 3). The protohaem formation observed may have resulted from the conversion of non-reduced protoporphyrin, since the complete reduction of the porphyrin to porphyrinogen was difficult without concurrent reduction of the vinyl groups. For this reason mesoporphyrinogen was also tested but found to be inactive.

Effect of reduced glutathione on ferrochelatase activity. Labbe \& Hubbard (1960) have claimed that ferrochelatase is a sulphydryl enzyme that can be activated by preincubation with GSH. Attempts to confirm this were unsuccessful (Table 4).

Valency of iron in ferrochelatase reaction. The results in Table 5 demonstrate that $\mathrm{Fe}^{2+}$ ions, but not $\mathrm{Fe}^{3+}$ ions, are used by ferrochelatase. It is possible therefore that the stimulation of ferrochelatase activity by GSH observed by Labbe \& Hubbard (1960) was due not to the protection of essential sulphydryl groups of the enzyme but rather to the ability of GSH to maintain iron in the ferrous form under conditions that are not strictly anaerobic.

Effect of $\mathrm{pH}$ on ferrochelatase activity. The $\mathrm{pH}-$ activity curve for mesohaem formation (Fig. $3 a$ ), shows a peak at $\mathrm{pH} 7 \cdot 8$ and a shoulder at $\mathrm{pH} 9 \cdot 0$,

Table 3. Test of porphyrins and porphyrinogens as substrates of ferrochelatase

Ferrochelatase activity was determined in the presence of the various porphyrins and porphyrinogens (amounts specified) by the pyridine haemochromogen assay (see the Methods section). The incubation periods are shown in the Table.

\begin{tabular}{cl}
$\begin{array}{c}\text { Expt. } \\
\text { no. }\end{array}$ & \multicolumn{1}{c}{ Substrate } \\
1 & $\begin{array}{l}\text { Mesoporphyrin }(200 \mu \mathrm{m}-\mathrm{moles}) \\
\text { Mesoporphyrinogen }(200 \mu \mathrm{m}-\mathrm{moles})\end{array}$ \\
2 & $\begin{array}{l}\text { Protoporphyrin }(200 \mu \mathrm{m}-\mathrm{moles}) \\
\text { Protoporphyrinogen }(200 \mu \mathrm{m}-\mathrm{moles})\end{array}$ \\
3 & Protoporphyrin $(100 \mu \mathrm{m}-\mathrm{moles})$ \\
& Protoporphyrinogen $(100 \mu \mathrm{m}-\mathrm{moles})$
\end{tabular}

$\begin{array}{cc}\begin{array}{c}\text { Incubation } \\ \text { period } \\ \text { (min.) }\end{array} & \begin{array}{c}\text { Haem } \\ \text { formed } \\ (\mu \mathrm{m}-\mathrm{moles})\end{array} \\ 40 & 89 \cdot 9 \\ 40 & 0 \\ 120 & 29 \cdot 6 \\ 120 & 11 \cdot 2 \\ 120 & 14 \cdot 3 \\ 120 & 0\end{array}$


Table 4. Effect of reduced glutathione on mesohaem formation

Ferrochelatase activity was determined by the pyridine haemochromogen assay (see the Methods section) with the following modifications: 1 , standard conditions; 2 , without GSH; 3, enzyme extract preincubated in vacuo with GSH for $20 \mathrm{~min}$. at $37^{\circ}$.

$\begin{array}{cc}\text { Expt. } & \text { Mesohaem formed } \\ \text { no. } & (\mu \mathrm{m}-\mathrm{moles} / 20 \mathrm{~min} .) \\ 1 & 38 \cdot 0 \\ 2 & 47 \cdot 0 \\ 3 & 40 \cdot 0\end{array}$

\section{Table 5. Ferrous and ferric ions as substrates} for mesohaem formation

Ferrochelatase activity was determined in vacuo in Thunberg tubes by the pyridine haemochromogen assay (see the Methods section). Either $\mathrm{Fe}^{2+}$ or $\mathrm{Fe}^{3+}$ ions were used as the substrates in the presence and absence of GSH. The reactions were started by the addition of the sidearm contents and allowed to proceed for $30 \mathrm{~min}$.

$\begin{array}{cc}\text { Side-arm contents } & \begin{array}{c}\text { Mesohaem } \\ \text { formed } \\ (\mu \mathrm{m}-\mathrm{moles})\end{array} \\ \mathrm{FeSO}_{4} & \mathbf{3 3 \cdot 8} \\ \mathrm{FeSO}_{4}+\mathrm{GSH} & \mathbf{2 7 \cdot 6} \\ \mathrm{FeCl}_{3} & 0 \\ \mathrm{FeCl}_{3}+\mathrm{GSH} & 29 \cdot 8\end{array}$

whereas that for protohaem formation (Fig. $3 b$ ) reveals two peaks, one at $\mathrm{pH} 7.9$ and one at $\mathrm{pH}$ 8.9. To eliminate the possibility that the increased activity at $\mathrm{pH} 9.0$ might be due to the effect of high $\mathrm{pH}$ on porphyrin solubility, all incubations were performed in the presence of $1 \%$ $(\mathrm{w} / \mathrm{v})$ Emasol 4130. This detergent ensures the complete solubility of the porphyrin at both $\mathrm{pH} \mathbf{7 . 9}$ and $\mathrm{pH} \mathrm{9.0} \mathrm{(Porra} \mathrm{\&} \mathrm{Jones,} \mathrm{1963).} \mathrm{Non-}$ enzymic haem formation did not occur with mesoor proto-porphyrin at $\mathrm{pH} 7.8$ and $\mathrm{pH} \mathrm{9.0}$ under conditions otherwise identical with those described in Fig. 3.

${ }^{59} \mathrm{Fe}$ exchange reaction. Pig-liver extract $(1 \cdot 0 \mathrm{ml}$.) was incubated at $\mathrm{pH} 7.8$ in vacuo at $37^{\circ}$ for $1 \mathrm{hr}$. with $6 \cdot 6 \mu$ moles of $\left[{ }^{59} \mathrm{Fe}\right]$ ferric citrate, $15 \mu$ moles of protohaem and sufficient dithionite to maintain the haem in the reduced form. Of the added ${ }^{59} \mathrm{Fe}$, $1.25 \%$ was incorporated into the haem. No exchange was observed when the protohaem was replaced by haemoglobin or when boiled pig-liver extract was incubated with protohaem. The stabilizing effect of the protein on the iron in complex may be responsible for the stimulation of haem formation by globin (Schwartz, Hill, Cartwright \& Wintrobe, 1959). The increased solubility of protoporphyrin in the presence of globin may also contribute to this stimulation (cf. Heikel et al. 1958).
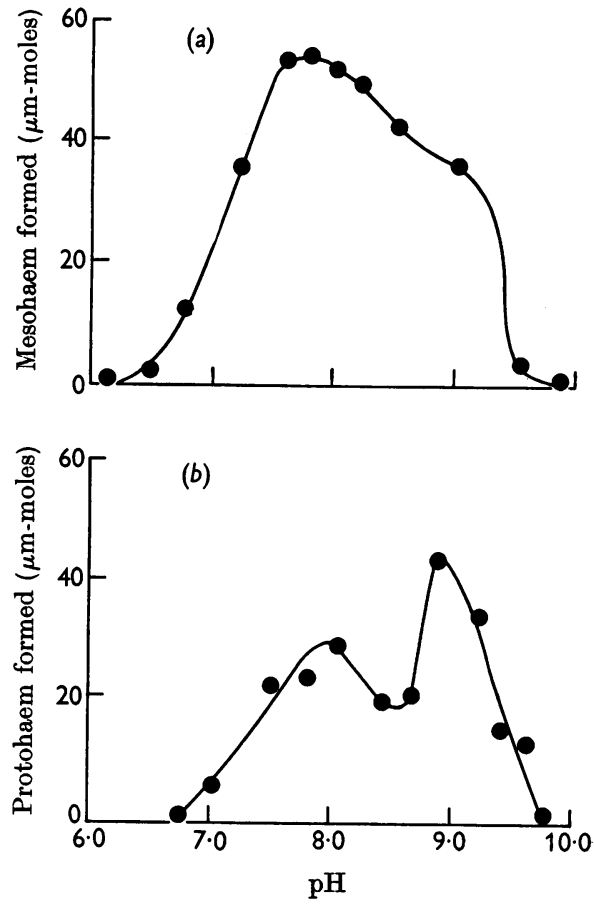

Fig. 3. Effect of $\mathrm{pH}$ on the formation of $(a)$ mesohaem and (b) protohaem. Ferrochelatase activity was determined in the presence of $1 \%(w / v)$ Emasol 4130 by the pyridine haemochromogen assay (see the Methods section). (a) Mesoporphyrin incubated with pig-liver extract ( $1.0 \mathrm{ml}$.) for 20 min.; (b) protoporphyrin incubated with pig-liver extract (2.0 ml.) for $40 \mathrm{~min}$. Solutions were buffered in the ranges $\mathrm{pH} 6 \cdot 0-7.8$ with potassium phosphate buffer, $\mathrm{pH} 7 \cdot 8-8 \cdot 6$ with tris- $\mathrm{HCl}$ buffer and $\mathrm{pH}$ 8.6-10.0 with glycine- $\mathrm{NaOH}$ buffer. The final concentration of all the buffers (see Gomori, 1955) was 0.05 M.

\section{DISCUSSION}

Previous assays of enzymic haem formation have involved the measurement of porphyrin disappearance or of newly synthesized [ $\left.{ }^{59} \mathrm{Fe}\right]$ haem (Oyama, Sugita, Yoneyama \& Yoshikaya, 1961; Labbe, 1959). Since the pyridine haemochromogen assay allows the haem that is formed to be identified it is useful in the study of the porphyrin specificity of ferrochelatase (Oyama et al. 1961). Quantitative determination of the synthesized haem from a difference spectrum of the reduced and oxidized forms eliminates the necessity to isolate the haem from the unconverted porphyrin. Details of several such pyridine haemochromogen difference spectra are presented by Porra \& Jones (1963).

The total inhibition by air of ferrochelatase activity in soluble extracts is interesting since there are many examples of aerobic haem synthesis in 
avian erythrocytes, crude haemolysates and liver homogenates. It is possible that secondary oxidative processes in these crude preparations may maintain anaerobic conditions at the site of iron insertion. The report of the abolition of the lag phase when ferrochelatase was preincubated with protoporphyrin (Nishida \& Labbe, 1959) or GSH (Labbe \& Hubbard, 1960), which we were unable to demonstrate in vacuo, may, like the lag phase itself, be due to the time necessary for the stream of nitrogen to remove all the oxygen from the incubation flask.

Uroporphyrinogen III (Nevé, Labbe \& Aldrich, 1956) and coproporphyrinogen III (Granick \& Mauzerall, 1958; Sano \& Granick, 1961; Porra \& Falk, 1961), but not the corresponding porphyrins (Dresel \& Falk, 1956), are known to be intermediates in the biosynthesis of haem. Porra \& Falk (1961) and Porra (1962) have shown that a reduced form of protoporphyrin, probably protoporphyrinogen, was formed during the enzymic conversion of coproporphyrinogen III into protoporphyrin IX. The inability of ferrochelatase to utilize porphyrinogens suggests that this is the first reaction in haem biosynthesis to use a porphyrin as substrate. Evidence has been presented (Sano \& Granick, 1961) that liver mitochondria contain a protoporphyrinogen oxidase.

Between pH 7.8 and 9.0 the carboxylic acid groups of meso- and proto-porphyrin are completely ionized, whereas the pyrrole nitrogen atoms remain completely un-ionized (Phillips, 1960). It seems unlikely therefore that the asymmetric shapes of the pH curves can be due to the ionization behaviour of the porphyrins; they could be explained, however, by the existence of two enzymes differing in $\mathrm{pH}$ optima with overlapping specificity. Evidence for the existence of more than one type of ferrochelatase has been found during a comparison of extracts from different sources (Porra \& Jones, 1963).

\section{SUMMARY}

1. A rapid and versatile assay for ferrochelatase has been described which involves the measurement of pyridine haemochromogen spectra.

2. A ferrochelatase extract from pig liver was most active when incubated in vacuo: activity was completely inhibited by aerobic conditions.

3. Ferrochelatase inserted $\mathbf{F e}^{2+}$ ions, but not $\mathrm{Fe}^{3+}$ ions, into mesoporphyrin.

4. GSH stimulated activity only when iron was added in the ferric form.

5. Meso- and proto-porphyrins were substrates for ferrochelatase but the corresponding porphyrinogens did not appear to be used. No accumulation of reduced porphyrin intermediates could be detected.
6. The pig-liver extract will not catalyse the exchange of $\mathrm{Fe}^{2+}$ ions with haemoglobin but the reversibility of haem formation from protoporphyrin has been demonstrated.

We thank Dr J. E. Falk for his interest and also Professor A. H. Ennor and other members of the Department of Biochemistry, Australian National University, for helpful discussions. One of us (O.T.G.J.) thanks Fisons Pest Control Ltd., Harston, Cambs., for financial support.

\section{REFERENCES}

Drabkin, D. L. (1949). Arch. Biochem. 21, 224.

Dresel, E. I. B. \& Falk, J. E. (1956). Biochem. J. 63, 388.

Gomori, G. (1955). In Methods in Enzymology, vol. 1. p. 138. Ed. by Colowick, S. P. \& Kaplan, N. O. New York: Academic Press Inc.

Granick, S. \& Mauzerall, D. (1958). Fed. Proc. 17, 233.

Heikel, T., Lockwood, W. H. \& Rimington, C. (1958). Nature, Lond., 182, 313.

Hoare, D. S. \& Heath, H. (1958). Nature, Lond., 181, 1592. Labbe, R. F. (1959). Biochim. biophys. Acta, 31, 589.

Labbe, R. F. \& Hubbard, N. (1960). Biochim. biophys. Acta, 41, 185.

Labbe, R. F. \& Nishida, G. (1957). Biochim. biophys. Acta, 26, 437.

Lemberg, R. (1961). In Haematin Enzymes, p. 216. Ed. by Falk, J. E., Lemberg, R. \& Morton, R. K. Oxford: Pergamon Press Ltd.

Lowry, O. H., Rosebrough, N. J., Farr, A. L. \& Randall, R. J. (1951). J. biol. Chem. 193, 265.

Mahler, H. R., Wakil, S. J. \& Boch, R. M. (1953). J. biol. Chem. 204, 453.

Mauzerall, D. \& Granick, S. (1958). J. biol. Chem. 232, 1141.

Morell, D. B. \& Stewart, M. (1956). Aust. J. exp. Biol. med. Sci. 34, 211.

Nevé, R. A., Labbe, R. F. \& Aldrich, R. A. (1956). $J$. Amer. chem. Soc. 78, 691.

Nishida, G. \& Labbe, R. F. (1959). Biochim. biophys. Acta, 31, 519.

Orlando, J. A. (1958). Ph.D. Thesis: University of California.

Oyama, H., Sugita, Y., Yoneyama, Y. \& Yoshikaya, H. (1961). Biochim. biophys. Acta, 41, 413.

Paul, K.-G., Theorell, H. \& Åkeson, Å. (1953). Acta chem. scand. 7, 1284.

Phillips, J. N. (1960). Rev. pure appl. Chem. 10, 35.

Phillips, J. N. (1961). In Haematin Enzymes, p. 214. Ed. by Falk, J. E., Lemberg, R. \& Morton, R. K. Oxford: Pergamon Press Ltd.

Porra, R. J. (1962). Ph.D. Thesis: Australian National University.

Porra, R. J. \& Falk, J. E. (1961). Biochem. biophys. Res. Commun. 5, 179.

Porra, R. J. \& Jones, O. T. G. (1963). Biochem. J. 87, 186.

Rimington, C. (1958). Rev. pure appl. Chem. 8, 129.

Sano, S. \& Granick, S. (1961). J. biol. Chem. 236, 1173.

Schwartz, H. C., Hill, R. L., Cartwright, G. E. \& Wintrobe, M. M. (1959). Biochim. biophys. Acta, 36, 567.

Weissberger, A., Proskauer, E. S., Riddick, J. A. \& Toops, E. E. (1955). Organic Solvents: Physical Properties and Methods of Purification, p. 365. New York: Interscience Publishers Inc. 